\title{
The late spring Caribbean rain-belt: climatology and dynamics
}

\author{
Theodore L. Allen ${ }^{\mathrm{a} *}$ (1) and Brian E. Mapes ${ }^{\mathrm{b}}$ (]) \\ ${ }^{a}$ The International Institute for Climate and Society, Earth Institute, Columbia University, Palisades, NY, USA \\ ${ }^{\mathrm{b}}$ Department of Atmospheric Sciences, Rosenstiel School of Marine and Atmospheric Science (RSMAS), University of Miami, Miami, FL, USA
}

\begin{abstract}
This study examines the dynamics of late spring rainfall (the Early Rainy Season, ERS) in the Caribbean region, in hopes of identifying mechanistic-based predictors for low-frequency climate modulations of the system. The subtropical Caribbean rain-belt develops in May as seasonal warming proceeds. By July, the rain-belt retreats north apparently following the westerlies and their vigorous synoptic disturbances. Daily climatology data suggest a physical definition of the Caribbean ERS as mid-May to mid-late June. Based on an examination of daily loops for several seasons, we hypothesize that rainfall occurs quasi-randomly throughout tongues of air with sufficiently high (above $45-50 \mathrm{~mm}$ ) precipitable water (PW). These moist airmasses are brought north from the deep tropics by low-level southerlies, and typically bent over into SW-NE bands by latitudinal shear of the westerlies. The low-level flow that transports PW tongues is partly induced by upper-level synoptic disturbances in the westerlies, but also involves the gentle persistent flow around a geographically anchored Panama Low. While forced ascent is sometimes active ahead of these upper-level troughs, convective and mesoscale processes can produce rain wherever PW is sufficient. In summary, we hypothesize that rainfall hinges largely on the Lagrangian statistics of moist air tongues. Comparison is drawn between the Caribbean rain-belt and its East Asian counterpart (Meiyu-Baiu), and other mechanisms and diagnostics from that literature are discussed. Statistical prediction exercises, based on mechanistically chosen predictors, could both test hypotheses and aid local agricultural interests in the region.
\end{abstract}

KEY WORDS Caribbean precipitation; Caribbean rain-belt; mid-summer drought; Caribbean early rainfall season; Caribbean; precipitation

Received 2 September 2016; Revised 6 March 2017; Accepted 18 April 2017

\section{Introduction}

Rainfall during the early rainy season (ERS) is critical for Caribbean agriculture during the early growing season (Gamble et al., 2010). Reduced rainfall after the ERS results in a decline in vegetation health during the mid-summer (Allen et al., 2010). Definitions of the ERS vary, sometimes April to July, or May to July (Spence et al., 2004), or May to June (Chen and Taylor, 2002). Our goal here is to clarify thermodynamic and dynamical mechanisms driving the ERS, in order to choose physically based statistical predictors for year-to-year variability.

Thermodynamically, ERS onset may depend on crossing of a sea surface temperature (SST) threshold for deep convection, about $26-27^{\circ} \mathrm{C}$ in the tropics depending upon region and season (Waliser and Gautier, 1993). The Atlantic Warm Pool (AWP), a boreal summer warm water feature, satisfies the SST criterion for deep convection in the Caribbean. Evaporation from warm water can help to elevate column integrated water vapour or total precipitable water (TPW), which may exert the more direct or proximate control on convection. Still, whether direct

\footnotetext{
* Correspondence to: T. L. Allen, The International Institute for Climate and Society, Earth Institute, Columbia University, 61 Route 9W, Palisades, NY 10964-1000, USA. E-mail: tallen@iri.columbia.edu
}

or indirect, the dependence of rainfall on SST helps motivate and explain interannual variability. Previous studies suggest that Caribbean rainfall variations may be driven by fluctuations in local SST (Curtis, 2013), and AWP onset date exhibits similar variability with ERS onset dates (Misra et al., 2014).

Dynamical mechanisms also appear to play a role in governing rainfall, with implications for its interannual variability. Regional climate involves open systems, subject to external influences as well as internal sources of variability. Understanding the basic system of interest (in this case, a rain-producing weather pattern) is not only of intrinsic interest, but also can help guide the practical search for associations with possibly predictable remote or large-scale influences. One path towards such an understanding is through deduction from the basic facts of mean seasonality. Another path involves interpretation of samples of the actual instantaneous weather that makes rain.

In this study, we show that the Caribbean late-spring ERS is best defined physically as mid-May to mid-June, rather than in calendar monthly mean averages. We hypothesize that ERS onset may be governed by seasonal warming and moisture availability, while its demise (the onset of July's drier conditions) may be more dynamical, tied to the retreat of the midlatitude westerlies and their troughs, in conjunction with the enhancement of easterly flow 
at all levels, and attendant enhanced low-level easterly trades on the flank of the dry Atlantic Subtropical High. These hypotheses can guide research into the causes and predictability of ERS interannual variability, which could both aid regional interests and also serve as an arena for testing the hypotheses themselves.

Towards these goals, this paper reviews the mean spring-summer climatology of the region (Section 3), examines synoptic processes during the ERS, summarized in a schematic (Section 4), and makes comparisons to the better-studied analogue of East Asia (Section 5). Conclusions and prospects for increasing understanding further are considered in Section 6.

\section{Data sources}

For this study, gridded precipitation estimates covering land and water are favoured over station observations, since regional patterns are our subject, not quantitative values on rugged heterogeneous terrain. Principally we use the $0.25^{\circ}$ Tropical Rainfall Measuring Mission 3B42 (Huffman et al., 2007), a three-hourly original data product examined here in daily means from 1998 to 2012. Some figures also use GPCP (Adler et al., 2003) or interpolated outgoing longwave radiation (OLR, Liebmann and Smith, 1996) to characterize cloud and rain patterns, as mentioned in captions and text. The Modern Era Retrospective Analysis for Research and Applications dataset (MERRA, Rienecker et al., 2011) was used to analyse moisture (TPW) and other fields, along with the older NCEP-NCAR Reanalysis I (Kalnay et al., 1996) for some meteorological fields. None of our mostly qualitative conclusions hinge on the modest quantitative differences among these gridded data products and reanalyses.

\section{Caribbean region summer rainfall}

In this section, mean climatology is shown and described (Section 3.1), followed by a brief review of studies of low-frequency modulations and how they relate to the basic phenomenology (Section 3.2).

\subsection{Climatological mean and seasonal patterns}

The summer mean rainfall pattern in the region is shown in Figure 1. Local features related to continents, islands, peninsulas, and perhaps the Gulf Stream are superposed on a very broad scale underlying SW-NE tilted zone of rainfall. However, this seasonal accumulation pattern blurs together distinct subseasonal regimes, as we shall see.

The annual rainfall cycle over the Caribbean basin reveals a distinct bimodal pattern, with peaks during the late-spring and late-summer months, as seen in Figure 2(a)'s climatological (January-December) GPCP rainfall time series in each grid cell of the region. In many places, a relative minimum during the mid-summer, known as the mid-summer drought (MSD) (Magaña et al., 1999), separates the Primera or the ERS from the late-rainfall season (LRS) precipitation peak. During this midsummer period, some of the farthest north boxes in Figure 2(a) have their peak rain. The complementary timing of these events (emphasized by the larger area averaged red $v s$ black series in Figure 2(b)) suggests that a moving rain-belt, retreating into middle latitudes along with the summer jet stream, may be a more relevant description of the onsets and demises of sub-season features in local time series. Karnauskas et al. (2013) offer related observations and interpretations. Following the MSD, a second and longer-lasting (see Figure 2(b)) rainfall peak in the Caribbean during the LRS coincides with the warmest SST and a higher frequency of passing easterly waves and tropical storms.

As an aside, the influence of the Gulf Stream on the midlatitude mid-summer rainfall has been considered in modelling studies (Minobe et al., 2008; Kirtman et al., 2012). However, results suggest that a climatological rain-belt in those latitudes exists even in the presence of a smoothed SST field that eliminates the pattern of the warm Gulf Stream (Yoshida et al., 2010).

The sub-seasonal pattern evolution is clearer in Figure 3, showing climatological mean rainfall, sea level pressure, low-level winds, low-level and upper-level geopotential heights, and SST for April (top), the ERS (middle), and July (bottom). In April the Caribbean is under westerlies (Z250 contours) but apparently is still too cool for abundant convection and rainfall (SST). In July, Caribbean conditions are warm and rain occurs over the islands, but the upper-level westerlies (and thus their disturbances) are confined north of Florida. Only in the ERS does the rainfall span ocean and land across the Greater Antilles. A distinct dry zone through the Gulf of Mexico is seen during the ERS, which suggests that simple west-to-east motion of rain-producing mid-latitude fronts along the mean westerlies cannot explain the pattern in the Caribbean. This distinct belt will hereafter be referred to as the Caribbean rain-belt. On average, the Caribbean rain-belt extends diagonally from the Southwestern Caribbean across the Greater Antilles and into The Bahamas along approximately $13^{\circ}-24^{\circ} \mathrm{N}$.

A southerly flow component at low levels (implying a flux of tropical moisture into the region) is also prominent in the ERS, while the flow is more zonal in April and July towards the western Caribbean. Specifically, the $850 \mathrm{hPa}$ meridional wind time series (Figure 4) gives another clear indicator for defining the ERS from mid-May to mid-June, and may be a response to the latent heating arising from condensation throughout the rain-belt (as suggested by the model calculations in the Appendix of Sampe and Xie, 2010), not an external cause. Besides following the flank of the North Atlantic Subtropical High (NASH), geostrophic flow at low levels is also affected by a smaller-scale heat low (a mild trough in the pressures and heights) near the Caribbean coasts of Panama and Colombia, known locally as the Panama Low. A region of deep convection and moisture convergence regularly occurs around the Panama Low, which contributes to the formation of meso-scale convective clusters (Poveda and Mesa, 2000). 


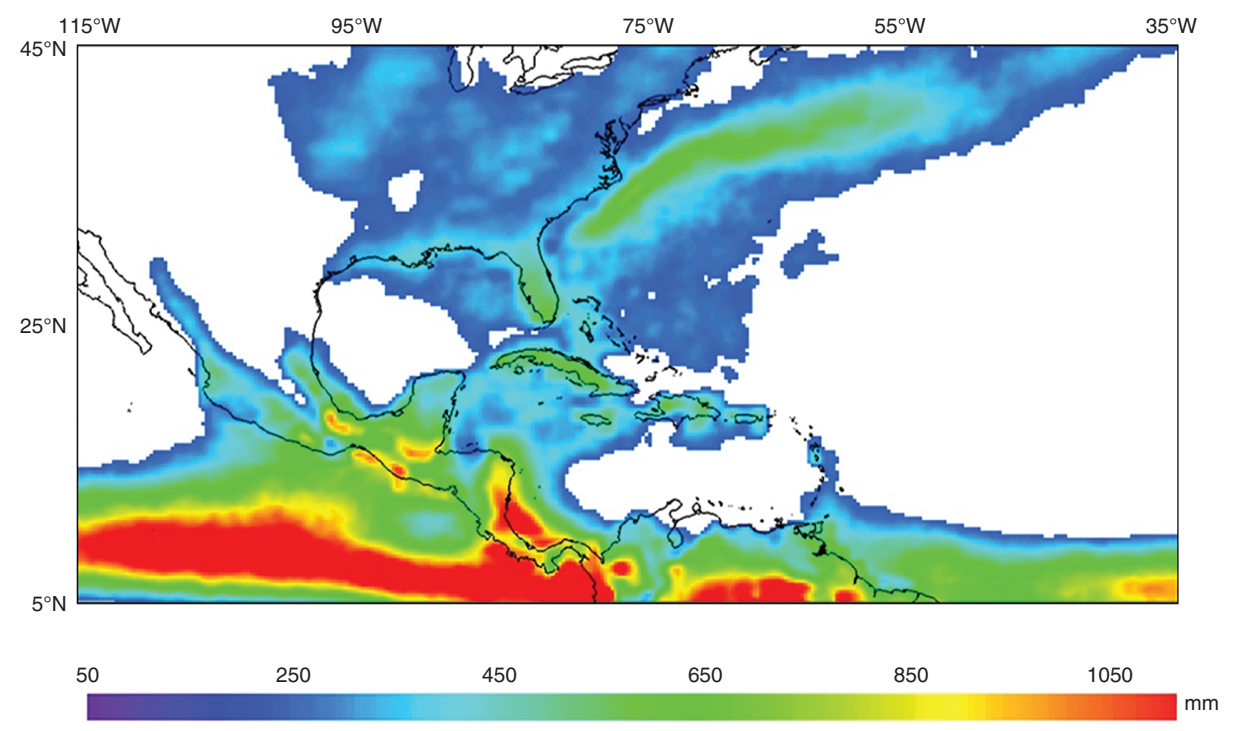

Figure 1. Average accumulated rainfall (mm) between 15 May and 31 July (1998-2012, TRMM 3B42).

During July, surface pressure in the western Caribbean has a 'bump' described by Curtis and Gamble (2008) and Mapes et al. (2005) during the MSD, as the NASH extends further into the western Caribbean. This may contribute to the drying during the MSD period (Kelly and Mapes, 2011).

\subsection{Low-frequency (interannual) modulations}

Recall that a goal in describing the climatology of the Caribbean rain-belt system was to seek influences that may also explain year-to-year differences. Interannual variability is observed in annual rainfall totals, length of the rainy season and length and timing of the MSD (Magaña et al., 1999; Jury et al., 2007; Curtis and Gamble, 2008; Gamble et al., 2008; Angeles et al., 2010). Various mechanisms have been proposed to explain the MSD, including regional SST anomalies (Magaña et al., 1999), a westward extension of the NASH (Giannini et al., 2000; Kelly and Mapes, 2011), variations in the summertime Caribbean Low-Level Jet (Muñoz et al., 2008), contributions from Saharan dust (Angeles et al., 2010), and the twice-a-year crossing of the solar declination (Karnauskas et al., 2013). However, the dynamics responsible for the onset and decay of rainfall in the Caribbean during the ERS along with its associated variability remain poorly understood. It is possible that a modified explanation of the MSD, cast as the cessation (or northward displacement) of the Caribbean rain-belt, may provide an additional way of understanding the mid-summer drying.

The El Nino-Southern Oscillation (ENSO) phenomenon is known to affect rainfall in the Caribbean region (Giannini et al., 2001; Chen and Taylor, 2002). Early season rainfall is reduced prior to a mature El Nino and is enhanced following a mature El Nino and during La Nina years. Drier than normal summertime conditions are exacerbated when a positive winter NAO phase is observed immediately prior to a developing El Nino (Giannini et al., 2001). The mechanism of ENSO and NAO influences appears to involve anomalous surface divergence and windspeed-induced SST anomalies in the Caribbean. But for any rain-producing weather system, warmer SST may also tend to increase rainfall through Clausius-Clapeyron effects alone, so a sensitivity to local or regional SST is not very discriminating about mechanisms. Dynamical mechanisms, ranging from the local tendency of warmer air, to rise to highly nonlocal effects from Asia via planetary-scale momentum fluxes (Kelly and Mapes, 2011, 2013), may contribute additional potentially predictable signals to Caribbean rainfall.

\section{A case study, schematic, and new hypothesis}

A positive relationship is seen between rainfall and upper tropospheric zonal wind (which steers disturbances) and rainfall in the Caribbean during the early summer months (Maloney and Esbensen, 2007; Small et al., 2007). More specifically, troughs steered by upper-level the westerlies are known to cause Caribbean wet spells (Jury et al., 2007), in agreement with SX10 Meiyu-Baiu conclusions. Does this imply that QG forcing for uplift, such as ahead of troughs due to positive vorticity advection aloft, is the driver? Not necessarily: Low-level manifestations of troughs include low-level cyclones with poleward flow from the tropics on their east side. Such flow transports moisture polewards, and broadly is directed up the mean equator-to-pole slope of mean isentropes (implying isentropic upglide, discussed further in Section 5). In any one case, or in blurred averages, the effects of dynamical lifting and northward moisture transport are therefore difficult to tease apart. The distinction may not matter for some purposes, but is worth drawing nonetheless since other flow components are also active.

Consider the situation on 23 May 2009, depicted in Figure 5. This image was selected, after viewing analogous imagery loops from multiple ERS seasons, for 


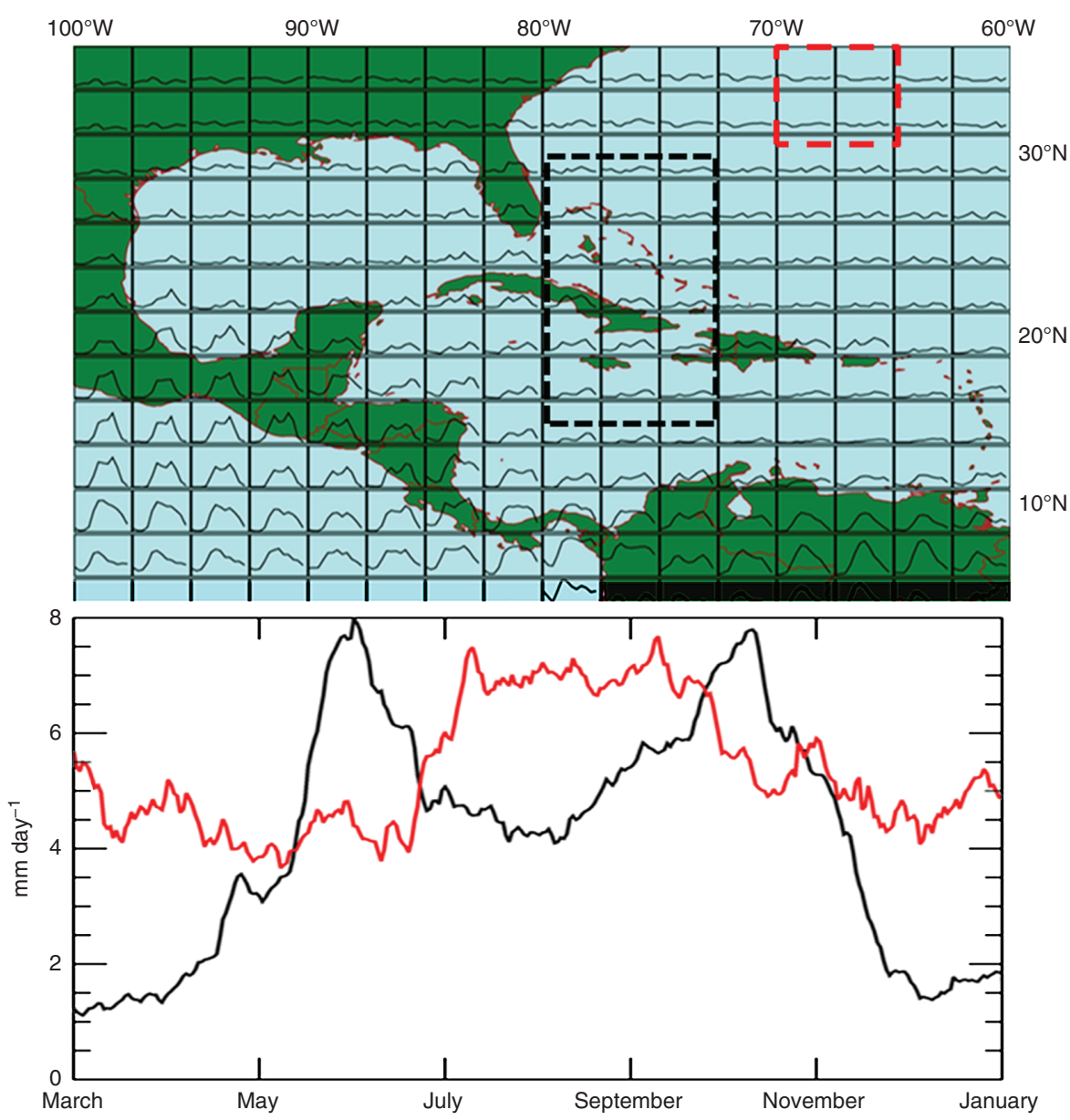

Figure 2. (a) Annual time series of climatological GPCP monthly rainfall in each $2.5^{\circ}$ grid cell from the $1979-2012$ period. Black and red dashed boxes represent the location of the Caribbean Sea and North Atlantic time series used in Figure 2(b). Notice the sharp onsets in late spring and double peak in the warm season. (b) Daily climatological time series of rainfall over the Caribbean Sea $\left(14^{\circ}-29^{\circ} \mathrm{N}, 80^{\circ}-75^{\circ} \mathrm{W}\right.$, black) and the western North Atlantic $\left(30^{\circ}-35^{\circ} \mathrm{N}, 70^{\circ}-65^{\circ} \mathrm{W}\right.$, red) from TRMM 3B42, 1998-2012. Based on this series, we define mid-May to mid-June as the Caribbean Early Rain Season (ERS).

being illustrative of the moisture versus dynamical forcing distinction. However, our subjective judgement is that it is not atypical of the varied weather situations making up the mean Caribbean rain-belt pattern. Two upper-level troughs in the westerlies (black height contours of $250 \mathrm{hPa}$ height) are inducing southerly flow in the lower-level flow (red arrows are short trajectories at $850 \mathrm{hPa}$ ) near the Panama Low region. These instantaneously indicated flow features have also existed at prior times, and thereby have displaced moist air columns (tongues in blue shading) northwards from their source in the humid deep tropics.

Substantial daily rainfall accumulations (magenta shading) are certainly seen in the strongly forced (lifted) frontal zone or warm conveyor belt to the east of the eastern trough and its cutoff. However, in addition to that strongly forced uplift band, rainfall is also scattered throughout the entire moist zone, which has been deformed into a complex shape by the various flow disturbances. In particular, the rainfall north of Puerto Rico and Hispaniola island, or southwest of Jamaica, are in upper-level ridge or straight-flow conditions that are not indicative of strong dynamical lifting.
Figure 5 was simply one sample map view of the rather close statistical relationship between TWP and precipitation (Bretherton et al., 2004; Peters and Neelin, 2006). In this fairly cool area of the tropics, a TPW exceeding $45-50 \mathrm{~mm}$ (as emphasized by the colour table) is a threshold-like predictor of rainfall, a necessary but not sufficient condition. The western Caribbean is notable for having high TPW yet little rainfall, a commonly observed anomaly in the region that deserves further study.

Animations of tongues of humid air (such as the lucid MIMIC-TPW imagery product, whose site http://tropic .ssec.wisc.edu/real-time/mimic-tpw/natl/main.html has archives of 72-hour loops) suggest that these are bent northeastwards by the increase of westerly flow with latitude. We hypothesize here that if rainfall occurs somewhat randomly within them, the SW-NE shape of the time-mean Caribbean rain-belt of the ERS may be explained as a Lagrangian statistical property of tracers (moisture) in the low-level flow. While the ultimate cause of that low-level flow is often induced circulation from upper-level potential vorticity filaments (tentacles of the polar vortex, broadly speaking), the proximate variable that shapes ERS rainfall is hypothesized to be the shape of TPW 

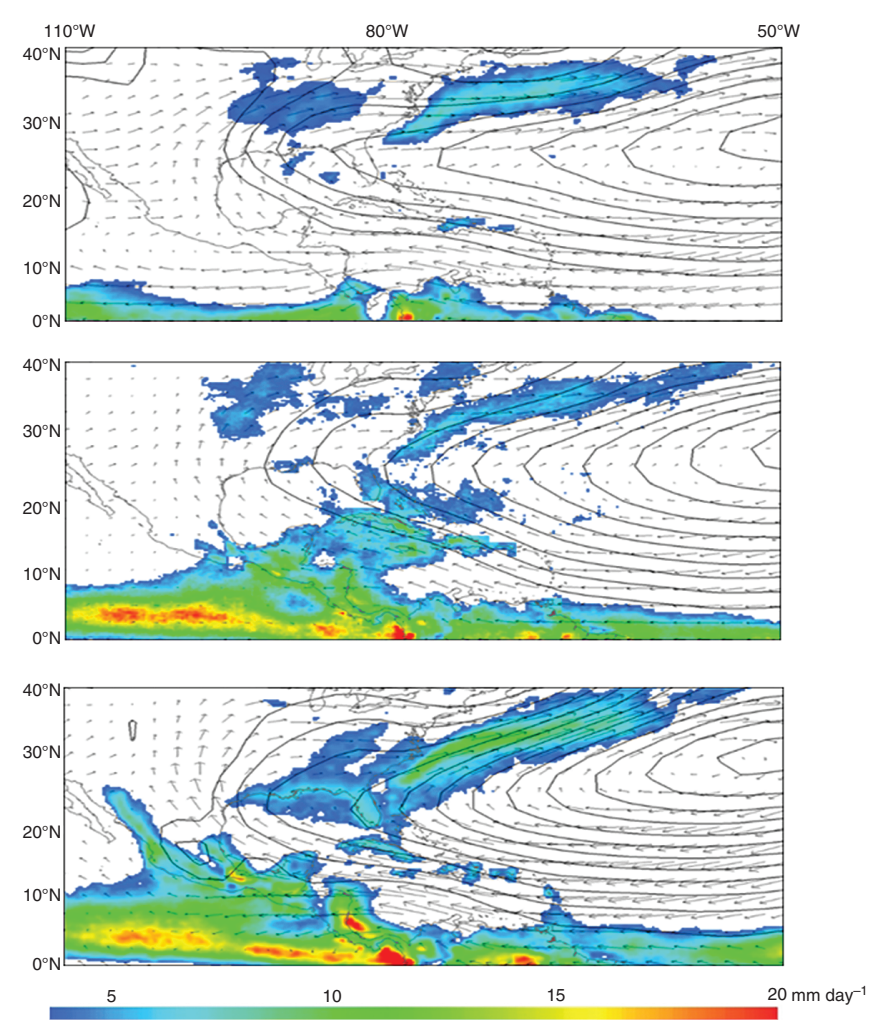
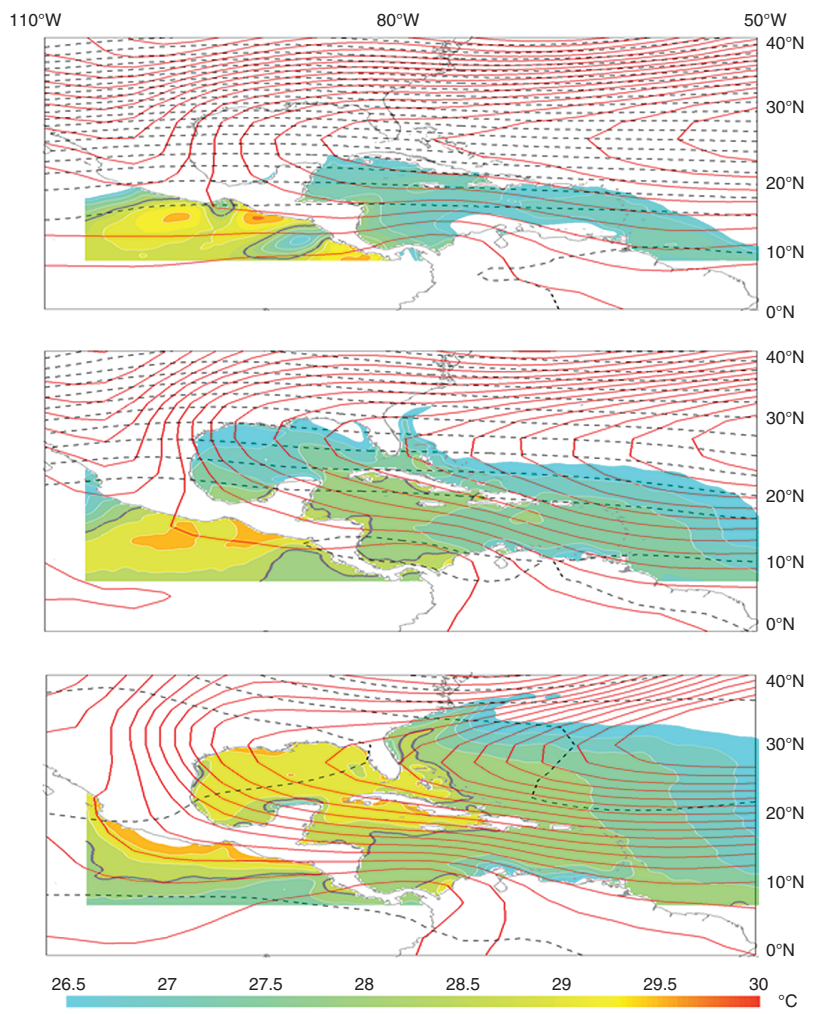

Figure 3. (a, c, e) Average sea level pressure isobars $(1 \mathrm{hPa}$ contours $>1014 \mathrm{hPa}), 850 \mathrm{hPa}$ wind vectors (max $\left.10 \mathrm{~m} \mathrm{~s}^{-1}\right)$, and TRMM 3B42 rain rate (shaded) for April (a), Early Rainfall Season (c), and July (e). Average baseline period calculated from 1998 to 2012 . (b, d, f) Average SST (shaded $>26.5^{\circ} \mathrm{C}$ ) and geopotential height for $850 \mathrm{hPa}$ (red contour) and $250 \mathrm{hPa}$ (black dashed contour) for April (b), Early Rain Season (d), and July (f). The $26.5^{\circ} \mathrm{C}$ isotherm is between the 26 and $27^{\circ} \mathrm{C}$ threshold for deep convection in the tropics. Atlantic Warm Pool isotherm (28.5 $\left.{ }^{\circ} \mathrm{C}\right)$ is indicated by a thick grey contour.

tongues. These tongues are necessarily advected by winds mainly in the lower half of the troposphere (see Mapes, 2000 for a review of tropical vertical structure issues), and can also form from the interaction of extra-tropical eddies and tropical diabatic heating (Park et al., 2015).

The Lagrangian properties of the low-level flow field that shapes the TPW field are not easy to foresee from Eulerian snapshots. Steady or slowly moving features have special influence in displacing tracers. For instance, many studies in the region emphasize a quasi-steady $925 \mathrm{hPa}$ Caribbean Low Level Jet (CLLJ) $\left(<-10 \mathrm{~m} \mathrm{~s}^{-1}\right)$ during the mid-summer. There has been considerable research linking variability in the CLLJ with Caribbean rainfall anomalies (Whyte et al., 2007; Muñoz et al., 2008; Martin and Schumacher, 2011; Taylor et al., 2013), but isotachs (which define 'jets') have no real place in theory. Instead, perhaps Lagrangian measures of the probability or frequency of occurrence of high TPW values provides a more satisfying (if harder to summarize) way to link precipitation features to flow features, favouring any combination of wide, strong, or quasi-stationary features.

Summarizing the lessons of Figures 3 and 5 and the many imagery loops we have examined, Figure 6 offers a schematic view of the climatological ERS (top) and its underlying dynamics, echoing the visual style of Figure 5 and sketched also from other data-based case studies. In this view, transients play a first-order role. Upper-level troughs (black height contours) drive unsteady low-level flows (red arrows) that advect humid air columns, within which rainfall (pink) occurs somewhat randomly, not merely in dynamically forced regions. Low-level troughs flow associated with the quasi-stationary Panama Low also supports transport of humid air from the tropics at low levels.

\section{Comparison to a well-studied analogue: Meiyu-Baiu or East Asian summer monsoon}

To enlarge our pool of candidate explanations for ERS dynamics, we turn to analogues in other longitudes. Figure 7 shows ERS minus July rainfall, in a domain stretched to include Asia as well as the Atlantic. North-south rainfall dipoles observed between the South China Sea and the Sea of Japan (approximately $26^{\circ}-36^{\circ} \mathrm{N}$, $110^{\circ}-130^{\circ} \mathrm{E}$ ) show that in Asia too the subtropical (and tropical) rainfall bands move northwards from ERS season to July. Similar poleward-eastward tilting subtropical rain-belt features are seen on the western edge of all the subtropical anticyclones (Kodama, 1992). These climatological features have various names, both region-specific and generic, such as subtropical convergence zones (STCZ) or precipitation zones; quasi-stationary rain-belts, or subtropical frontal zones (Ninomiya, 1984; Kodama, 1992; Enomoto et al., 2003; Sampe and Xie, 2010). Here we will use the term quasi-stationary rain-belt, 
(a) $-\mathrm{d}(\mathrm{phi} 850) / \mathrm{dx} 12-18^{\circ} \mathrm{N} 1998-2012$

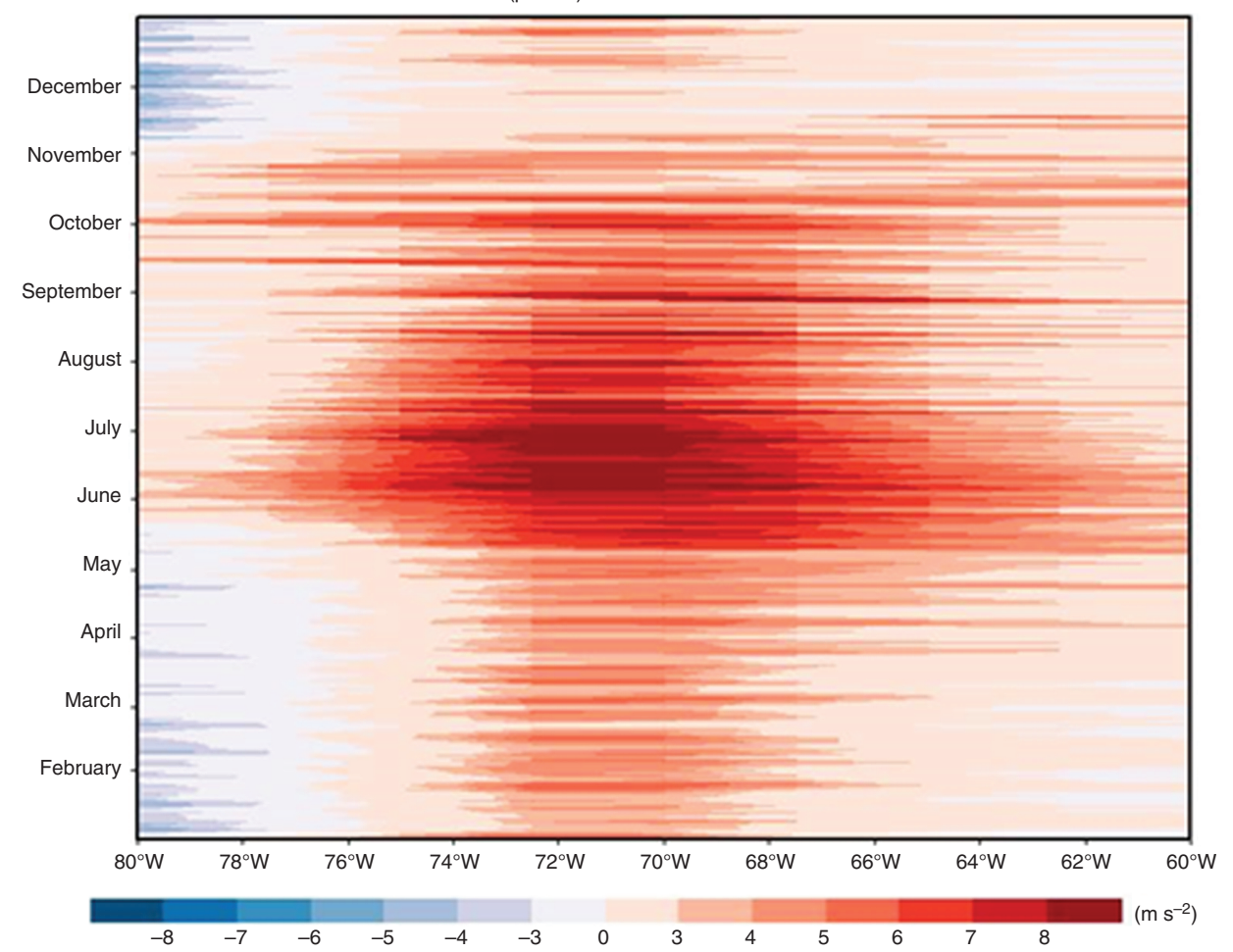

(b) annual cycle 850hPa v-wind

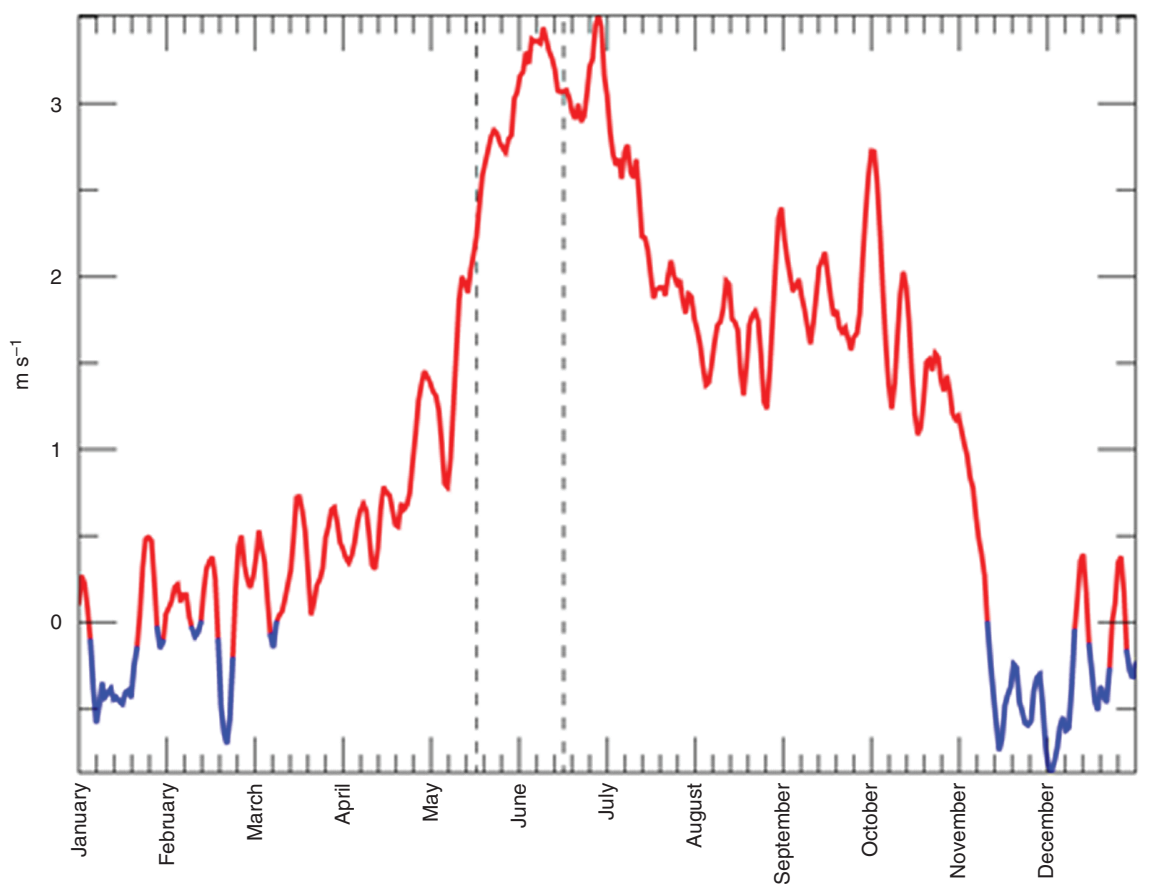

Figure 4. (a) Annual cycle of $850 \mathrm{hPa}$ geopotential zonal height gradients meriodionally averaged from 12 to $18^{\circ} \mathrm{N}$. Average baseline period calculated from 1998 to 2012. (b) Time series of area averaged meridional wind (red $>0 \mathrm{~m} \mathrm{~s}^{-1}$, blue $<0 \mathrm{~m} \mathrm{~s}^{-1}$ ) over the Caribbean region. Dashed vertical lines indicate the Early Rain Season period. Average baseline period calculated from 1998 to 2012.

where quasi-stationary applies on the monthly or seasonal timescale (not necessarily from day to day).

The East Asian early summer rain-belt is called Meiyu-Baiu, hyphenating Chinese and Japanese names (Ninomiya and Shibagaki, 2003). This rain-belt first appears near the South China Sea around mid-May (the Meiyu season) and migrates northwards towards Japan during the Baiu season where it abruptly ends in mid-July. Its climatological mean footprint is sometimes called the East Asian Summer Monsoon (EASM), and can be placed 


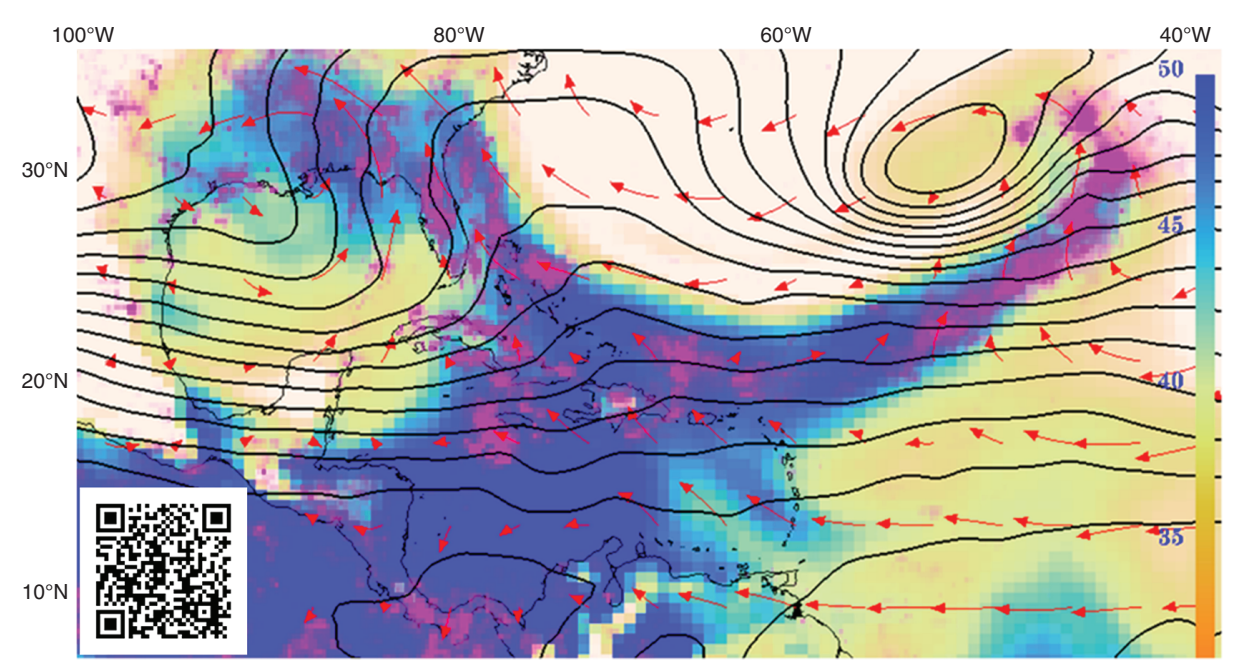

Figure 5. Synoptic map from 2009-05-23 showing daily column water vapour (mean of 1200 UTC and 0000 UTC in MERRA reanalysis, range 30-50 mm), daily accumulated rainfall from TRMM 3B42 (magenta shading, opaque for values $>50 \mathrm{~mm}$ ), and $1200 \mathrm{UTC}$ flow at $850 \mathrm{hPa}$ (curved red arrows are short-term trajectories) and $250 \mathrm{hPa}$ (black contours are geopotential height at $20 \mathrm{~m}$ intervals). Scan the QR code with a smartphone to watch a YouTube video of this 2009 case study.

in the broader regional context of the Asian monsoon system with maps of monsoon onset date (Wang et al., 2004; Wang, 2005). For a directly comparable depiction of Asian and North American monsoon onset progression, Figure 8 shows onset dates based on an objective wavelet analysis of the daily climatological time series of OLR (indicating deep convective clouds) at each point. Colour indicates the timing and strength of especially rapid decreases in OLR. Blue to red progressions indicating northward development over Asia are familiar from the many published maps of onset date, with annotations emphasizing the Indian Summer Monsoon, East Asian Summer Monsoon (EASM), and West Pacific Monsoon (WPM) which onsets rapidly starting in June. On the same scale and at the same latitudes and time of year as the EASM, we suggest that the Caribbean rain-belt may be viewed as an aspect of an analogous 'East North American Summer Monsoon' (ENASM).

Since the Caribbean rain-belt appears analogous to the EASM or Meiyu-Baiu in shape and seasonal evolution, perhaps its dynamics also are somewhat analogous. A recent study of Meiyu-Baiu dynamics by Sampe and Xie (2010, hereafter SX10) 'reveals the westerly jet as an important culprit for Meiyu-Baiu', both through its 'adiabatic induction of upward motion' by 'warm horizontal temperature advection' downwind of warm air of the southern Tibetan Plateau, and 'also by steering transient eddies ... creating periods conducive to convection.' They further cite 'low-level southerly winds as another important environmental forcing for Meiyu-Baiu by supplying moisture'. We shall see that many of these aspects are also present over the Caribbean region, although we may refine interpretation of water vapour's effect on convection as occurring through its presence, not quite by its 'supply' inferred from mean winds acting as a 'forcing'.
Upper tropospheric westerly subtropical jets are common to all STCZs (Kodama, 1993). In contrast to winter fronts over land, subtropical jet-front systems have relatively weak surface temperature gradients. Instead, the thermal gradient that hydrostatically supports the height gradient of the upper level jet to satisfy thermal wind balance is located in the middle troposphere (Shapiro, 1981). Disruptions of balance by frontogenesis and/or by momentum advection cause secondary circulations, in this case in the upper troposphere. For instance, Molinari and Vollaro (2012) related deep clouds in the subtropical Northwest Pacific to 'the dynamical forcing of vertical motion' ( $Q$ vector divergence) in the $400-200 \mathrm{hPa}$ layer. It remains somewhat unclear how such upper level quasi-geostrophic (QG) forcing is communicated to the lower troposphere where convection is governed.

Midlevel warm advection is another cause often cited for upward motion. In one view, warm advection is one of the two terms in the 'traditional' QG omega equation, as discussed in all synoptic textbooks (e.g. Lackmann, 2011). In a simpler view, SX10 emphasized its importance directly in the thermodynamic energy equation. When horizontal flow crosses $\mathrm{T}$ contours on an isobaric surface, yet those $\mathrm{T}$ contours are not moved (as is true of time mean flow), it implies a countervailing vertical advection by cross-isobaric (vertical) motion. More succinctly, a time-mean horizontal flow crossing a time-mean temperature gradient indicates adiabatic flow up a sloping isentropic surface (isentropic upglide). Such ascent can be further steepened in the tropics where ascending flow experiences diabatic heating from condensation and cloudy radiation. Can such an indication be inferred to be 'an external forcing', related to the warmth of air over the Tibetan Plateau, and 'inducing' the ascent, as in SX10's framing? Perhaps our geographical comparison can shed additional light on this question. 
(a)

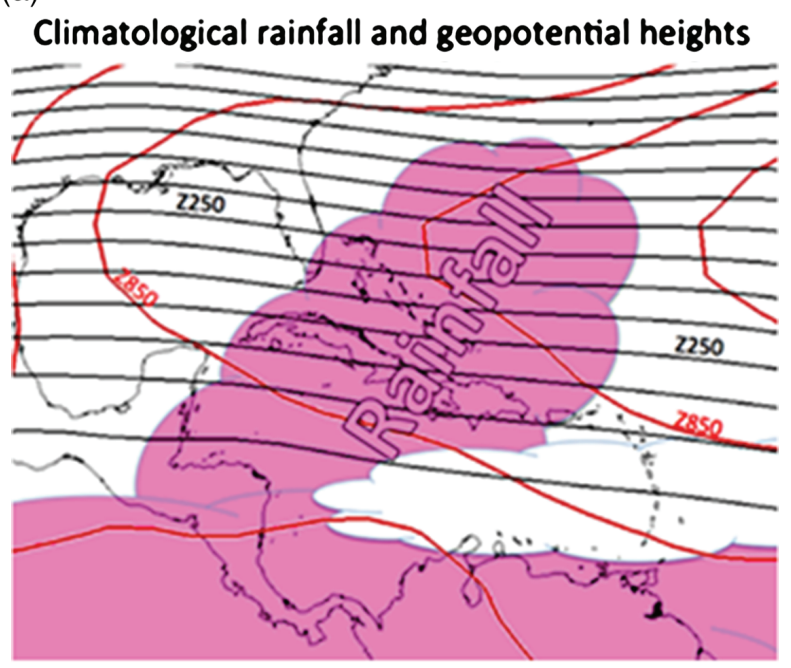

(b)

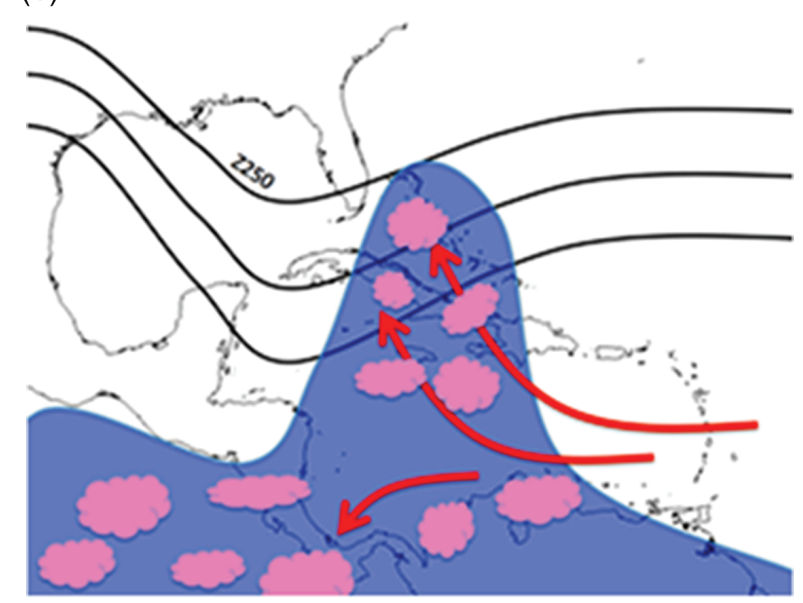

(c)

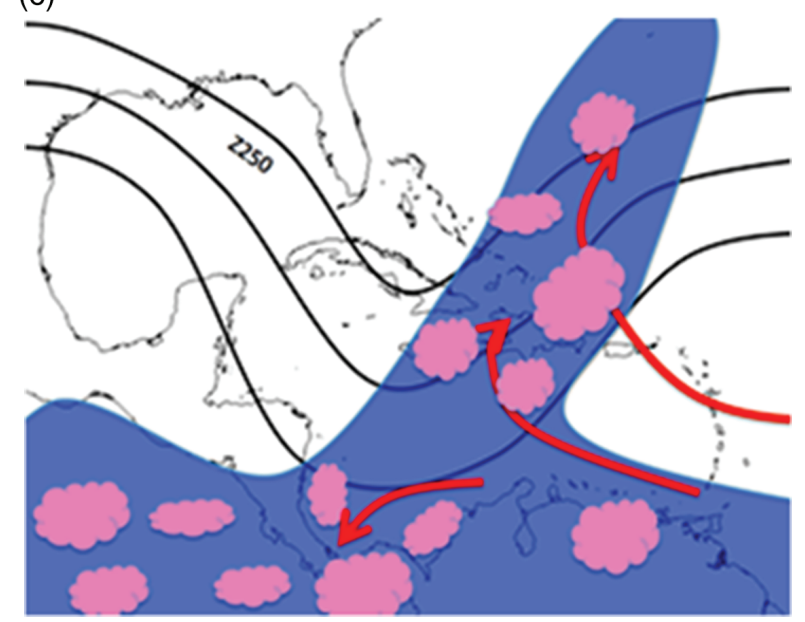

Figure 6. Schematic diagram representing the factors that contribute to the Caribbean rain-belt, based on imagery like Figure 5. Troughs in the westerlies induce southerly flow at low levels, which transports vapour northwards (blue tongues), especially if the trough is slow-moving or cuts off. Convective storms occur somewhat randomly within that moist air mass (pink), enhanced by quasi-geostrophic lifting ahead of the upper-level trough if it is strong. Diffluent flow associated with the Panama Low contributes a minimum in the western Caribbean Sea.
Figure 9 shows mean vertical motion and the advection of the time-mean $\mathrm{T}$ gradient by the time-mean flow in April, ERS, and July averages. Between the midlatitude westerlies and tropical easterlies, anticyclones straddle a temperature gradient. In the ERS in particular, the flow at $500 \mathrm{hPa}$ (Figure 9(c)) features an anticyclone with southerlies and warm advection (red contours in Figure 9(d)) over the Caribbean rain-belt region, and its corresponding upward motion (shading in Figure 9(a), (c) and (e)). In Figure 9, the temperature gradient is smoothly meridional, and lacks the eye-catching warmth at its western end emphasized by the hot colours of Figure 6 of SX10. Rather than viewing the implications of the time-averaged temperature budget as a forcing by topographic influences unique to Asia, perhaps a more agnostic view is that mean ascent in STCZs might be diagnosed or indicated by such mean-flow advection of mean warmth at midlevels, whatever its physical cause.

Perhaps the more time-resolved interpretations of SX10 are more incisive. Their arguments emphasize the rectified (cumulative) rainfall that occurs in transient disturbances, noting that this can 'explain a paradox' when time-mean fields are inappropriately used to make climate arguments. Diagnostic relations in averaged fields can be subtly misleading about causality - and thereby could misdirect our search for sources of variability and possible climate influences on the system.

\section{Summary and revisiting of the motivating question of climate modulation}

To summarize, climatology (Figures 1-3) of accumulated rainfall during the ERS shows a SW-NE band of rainfall, here called the Caribbean rain-belt, which extends from the Caribbean coast of Central America towards The Bahamas and occurs on average between mid-May and mid-June. The Caribbean rain-belt is not a globally unique feature; similar seasonal rain-belt patterns are observed elsewhere at subtropical latitudes. The dynamics of the Caribbean rain-belt were compared to the Meiyu-Baiu, a well-studied (SX10 and references therein) subtropical rain-belt over the western Pacific region. Our inquiry led us to emphasize low-level flow, via its steering or shaping effect on the TPW field (the envelope for semi-random convective rain events) through northward displacement of humid air columns from the deep tropics. In this view, strong transient influences originating at upper levels are important, but perhaps indirectly, through their effects at low levels. Also, steady (if weak) low-level flow components, especially the meridional flows component the Panama Low, may also be especially important, since persistent flow can displace tracers like water vapour very effectively.

A major motivation for this study of this climatological regional climate system was that understanding its dynamics might point us to possibly predictable sources of variability, especially remote effects that might not be as obvious as, say, local SST. Inter-annual variability of 


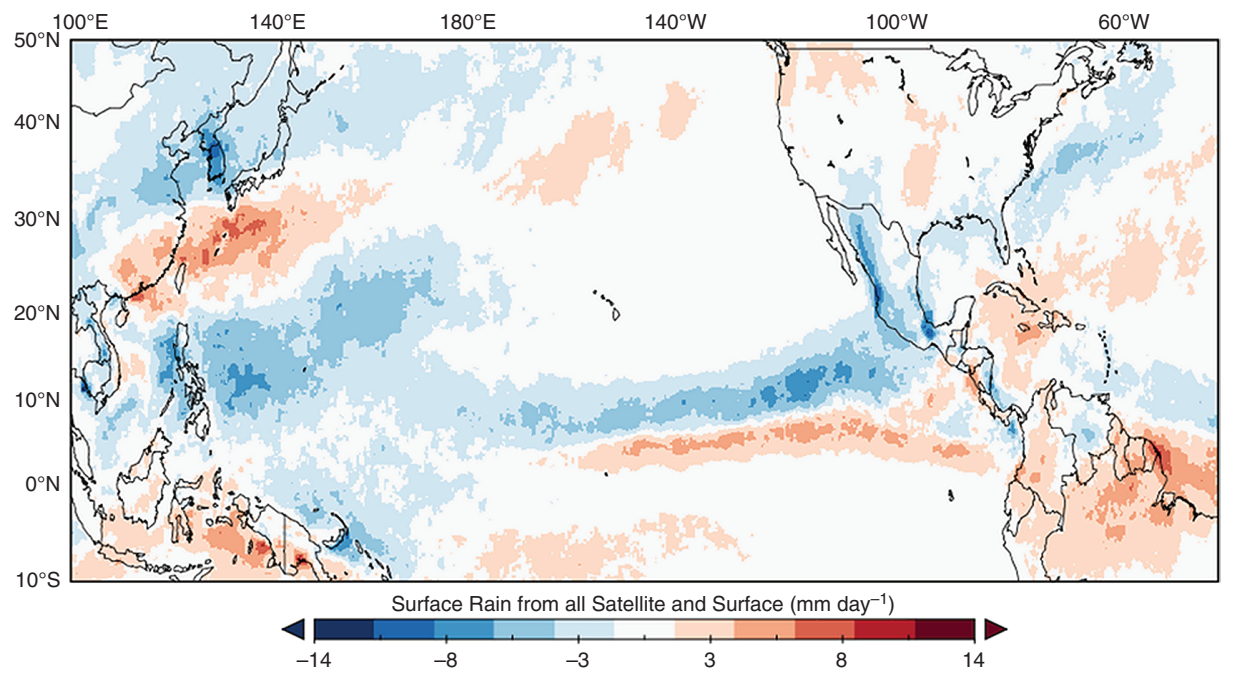

Figure 7. Climatological rain rate of the Early Rainfall Season, minus the July mean, from TRMM 3B42 data 1998-2012. Red colours indicate areas where ERS rain exceeds July rain: In the subtropics, this is over the Greater Antilles and in a belt just south of Japan.

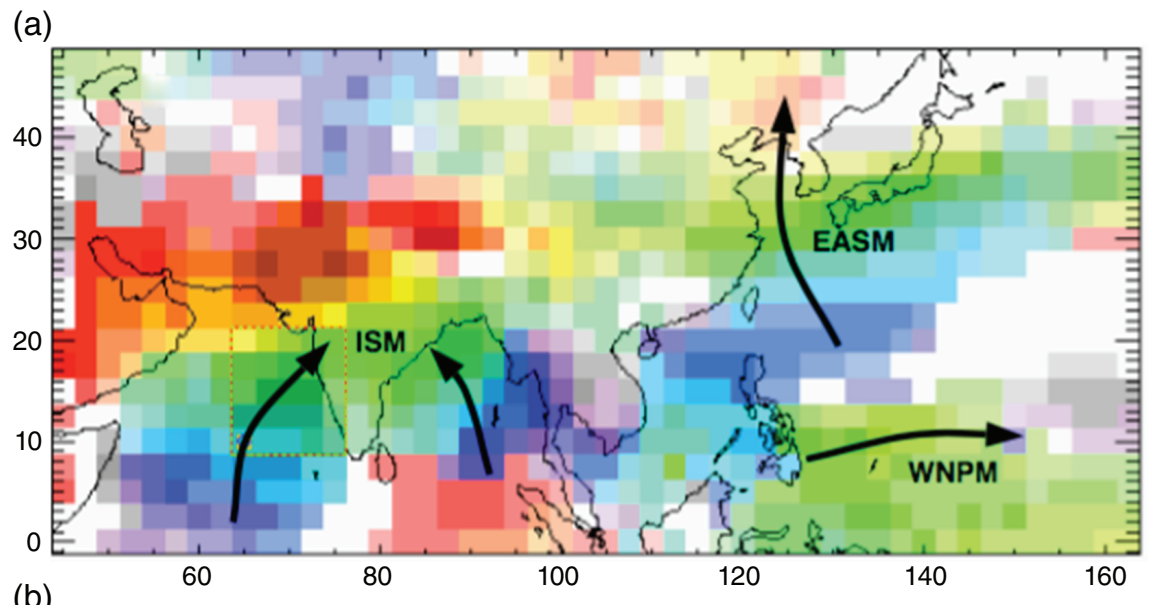

(b)

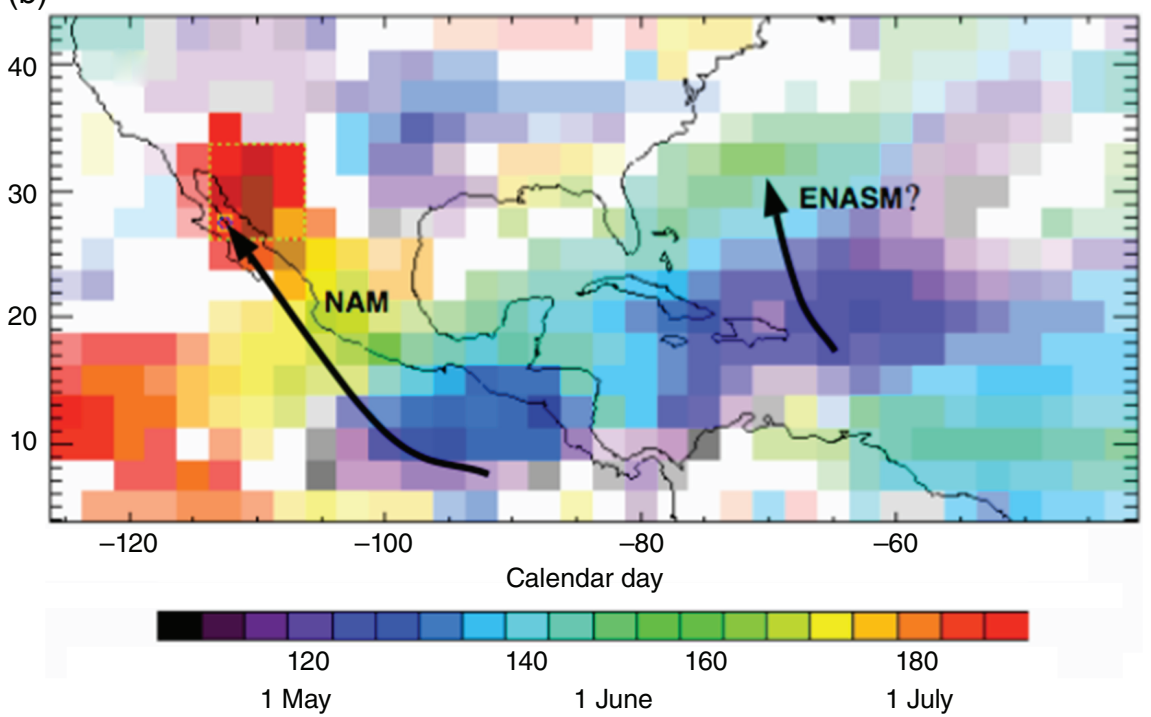

Figure 8. Date of sharp 'onset' of summer 'monsoon' cloudiness, derived from the climatological OLR time series at each point. The indicated date at each point is defined by the temporal location of the largest imaginary Paul wavelet power peak in the subseasonal band (25-140 day period) with its phase corresponding to a sharp decrease of the time series. The hue indicates date as indicated in the colour legend, while the density of coloration is proportional to the wavelet power peak's amplitude. If no power peak with a sufficient statistical significance index exists within the time interval, the grid cell is white, indicating there is no sharp increase in deep cloudiness in the spring-summer period indicated. 

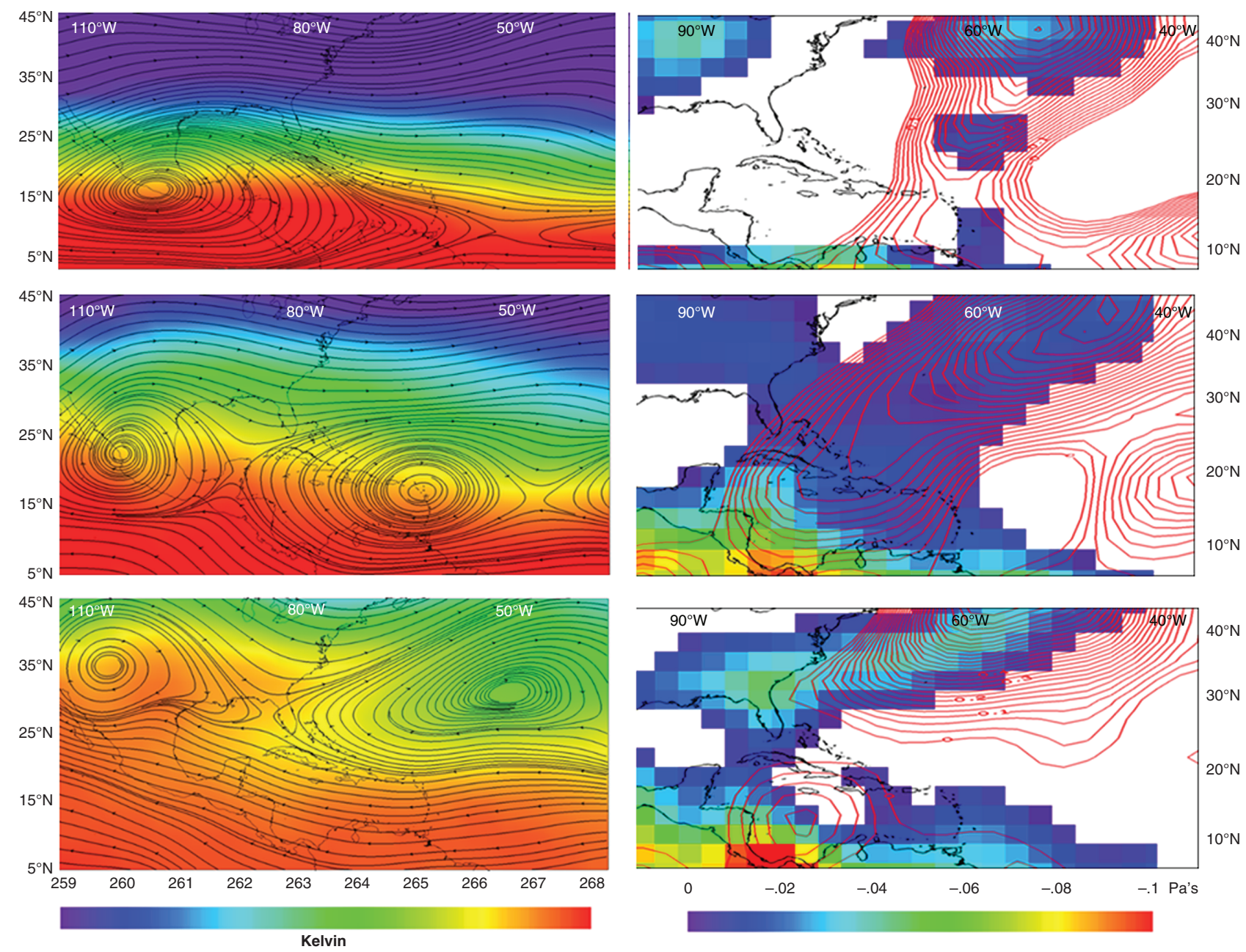

Figure 9. (a, c, e) Average $500 \mathrm{hPa}$ temperature and $500 \mathrm{hPa}$ streamlines for April (a), the Early Rainfall Season (c), and July (e). Average baseline period calculated from 1998 to 2012. (b, d, f) Average horizontal positive temperature advection (contours, $0.03 \mathrm{Ks}-1$ interval) and vertical velocity (shaded) at $500 \mathrm{hPa}$ for April (b), the Early Rainfall Season (d), and July (f). Climatology calculated from 1998 to 2012. Average baseline period calculated from 1998 to 2012.

the Caribbean rain-belt impacts farmers who depend on the regular cycle of rainfall during the ERS. The first author's outreach activities and capacity building workshops throughout the Caribbean revealed a real demand for predictions of ERS rainfall in an effort to increase farmer resilience to inter-annual rainfall variability.

To revisit this question, it is useful to view some year-to-year variability. Figure 10 shows how 15 individual years relate to their climatological mean. Large year-to-year irregularity suggests that just a few disturbances or statistical degrees of freedom per ERS, supporting the idea of a synoptic control like the TPW tracer statistics. Meanwhile, very spotty spatial texture suggests the importance of convective and mesoscale processes in the actual rain making events, not highly forced storms like trough-driven fronts or squalls that would paint rainfall across the Earth's surface semi-uniformly.

Figure 10 shows that the Caribbean rain-belt was prominent during 2012 and 2009 (motivating the choice in Figure 5), but is hard to identify in other years (1998, 2001, and 2004). In some years (2008 and 2011), the
Caribbean rain-belt is more zonal with a very weak southwest to northeast slope. Our hypothesis that TPW tongues as essential would suggest that these aspects might be usefully related (in future research) to the latitudinal shear at low levels, and thereby to factors that influence that including possibly global momentum dynamics like those explored in Kelly and Mapes (2011, 2013, 2016).

If the main mechanism identified by SX10 - warm horizontal temperature advection at $500 \mathrm{hPa}$ downwind of the Tibetan Plateau - were essential to Meiyu-Baiu rainfall, it might imply that Tibetan warmth (perhaps involving spring snowpack) would modulate Meiyu-Baiu rainfall year-by-year. But advection involves both a gradient and wind, so notwithstanding any anomalous mid-tropospheric warming, variability of a Eurasian westerly wave train embedded in westerly flow aloft remains a primary factor to the variability of the Meiyu-Baiu pattern (Kosaka et al., 2011).

Low-level southwesterly flow along the western edge of the subtropical high also acts as a moisture source to feed the rain-belt. Might its mechanisms governing that flow, 


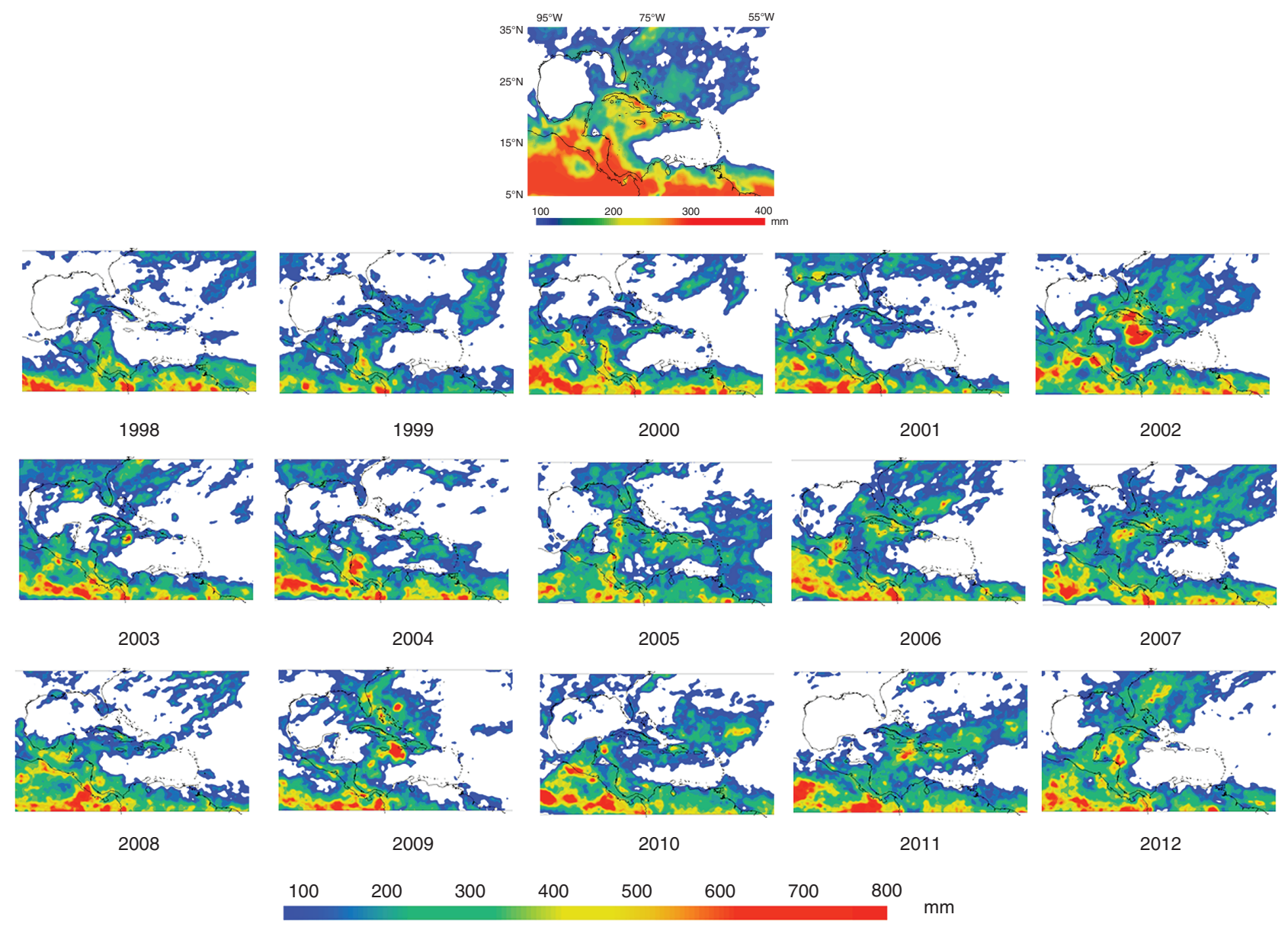

Figure 10. Accumulated Early Season rainfall for the 15-year mean (a) and the 15 individual years from 1998 to 2012 in TRMM 3B42 data (b). Rainfall accumulation under $100 \mathrm{~mm}$ is not shaded.

especially perhaps some weak but quasi-steady aspects of the flow, be an additional source of interannual variability? Subtropical highs are forced partly from the east as Rossby waves (Miyasaka and Nakamura, 2005).

Additional evidence for our hypothesis of TPW control of Caribbean rainfall is the weather observed during the drier winter months. Mid-latitude fronts during the winter can advance into the Caribbean (Liang, 2004), but rainfall along their path tends to be low. Winter flooding in the Caribbean is not totally uncommon, for instance the Christmas Day floods of 2012, which were associated with an out of season easterly wave. Usually, winter is dry because SST throughout the Caribbean Sea is well below convective instability thresholds. Southerly low-level flow out of the tropics is observed during the dry winter season, but energetic troughs and their low-level cyclones and fronts propagate through the Caribbean too quickly for their southerly flow and related moisture flux to persist as it does during the ERS. This illustrates the point that slow-moving transients have more effect, and suggests another set of variables that might modulate rainfall through the speed and scale (not just strength) of disturbances.

Rainfall does occur within the Caribbean during the MSD despite the absence of a westerly jet; however, scattered rainfall during that time is largely driven by instability from local diabatic processes; note the island-locked rainfall pattern in Figure 3(c). Over land, rainfall during the mid-summer is less dependent on high-TPW tongues.

Distinguishing between forced ascent by upper-level PV anomalies (troughs) versus the shaping of the moisture tracer field by low-level winds induced by upper-level PV anomalies may help us test our hypothesis. Unfortunately, these effects co-occur, as our case study indicates. To achieve statistical significance, we need many cases, which means we must devise measures (algorithms) that convincingly discriminate between these correlated patterns. Such an exercise is beyond the scope of this study. Broadly speaking, such a discriminator might exploit the linearity of induced flow versus the nonlinearity (through advection terms) inherent in QG forcing for ascent. The two effects might therefore scale differently with amplitude (strength) of the upper-level feature, a property illustrated by the strong front near the intense trough versus the broader tropical rain belt in our case study.

Another outcome from this research may be (yet another) alternative explanation for the onset of the MSD; several mechanisms were mentioned in Section 3. But if northward shift of the transients in the westerlies during mid-summer is essential, then the mechanism of impact on 
rainfall when easterlies replace westerlies (driven by Asian monsoon momentum dynamics; Kelly and Mapes, 2013, 2016) may need to be refined. Those authors emphasized the zonal displacement of the semi-permanent subtropical high and its weather conditions, but perhaps the steering of transients might be of first-order importance. Again, interannual variations might provide a test bed for distinguishing these mechanistic hypotheses, as well as a reason to care which one is more correct. To reiterate again, this research on characterizing a climatological rain pattern could for instance guide parameter selection for statistical modelling, motivated by applications that could benefit from forecasts.

\section{Acknowledgements}

The work described here was partly supported by the National Oceanic and Atmospheric Administration through the cooperative agreement NA13OAR4310184 and grant NA13OAR4310156, and by Office of Naval Research grant N000141310704, NASA grant NNX15AD11G, National Science Foundation (NSF) grant 0731520, and NASA grants NNX15AD11G and NNX13AQ50G. The views expressed are those of the authors and do not necessarily reflect the views of NOAA or its subagencies. Valuable discussions with the Climate Branch at The Jamaican Meteorological Service also helped to motivate this work. Integrated Data Viewer (IDV) software from UCAR/Unidata was used in the analysis and visualization of the data. Two anonymous reviewers helped to greatly improve the paper.

\section{References}

Adler RF, Huffman GJ, Chang A, Ferraro R, Xie P, Janowiak J, Rudolf B, Schneider U, Curtis S, Bolvin D, Gruber A, Susskind J, Arkin P, Nelkin E. 2003. The Version 2 global precipitation climatology project (GPCP) monthly precipitation analysis (1979-present). J. Hydrometeorol. 4: 1147-1167.

Allen TL, Curtis S, Gamble DW. 2010. The midsummer dry spell's impact on vegetation in Jamaica. J. Appl. Meteorol. Climatol. 49(7): 1590-1595. https://doi.org/10.1175/2010JAMC2422.1.

Angeles ME, González JE, Ramírez-Beltrán ND, Tepley CA, Comarazamy DE. 2010. Origins of the Caribbean rainfall bimodal behavior. J. Geophys. Res. 115(D11): D11106. https://doi.org/10 .1029/2009JD012990.

Bretherton CS, Peters M, Back L. 2004. Relationships between water vapor path and precipitation over the tropical oceans. J. Clim. 17: $1517-1528$

Chen AA, Taylor MA. 2002. Investigating the link between early season Caribbean rainfall and the El Nino +1 Year. Int. J. Climatol. 22(1): 87-106. https://doi.org/10.1002/joc.711.

Curtis S. 2013. Daily precipitation distributions over the intra-Americas sea and their interannual variability. Atmosfera 26(2): 243-259.

Curtis S, Gamble DW. 2008. Regional variations of the Caribbean mid-summer drought. Theor. Appl. Climatol. 94(1-2): 25-34. https:// doi.org/10.1007/s00704-007-0342-0.

Enomoto T, Hoskins BJ, Matsuda Y. 2003. The formation mechanism of the bonin high in August. Q. J. R. Meteorol. Soc. 129(587): 157-178. https://doi.org/10.1256/qj.01.211.

Gamble DW, Parnell DB, Curtis S. 2008. Spatial variability of the Caribbean mid-summer drought and relation to North Atlantic high circulation. Int. J. Climatol. 28(3): 343-350. https://doi.org/10.1002/ joc. 1600 .

Gamble DW, Campbell D, Allen TL, Barker D, Curtis S, McGregor D, Popke J. 2010. Climate change, drought, and Jamaican agriculture: local knowledge and the climate record. Ann. Assoc. Am. Geogr. 100(4): 880-893. https://doi.org/10.1080/00045608.2010.497122.

Giannini A, Kushnir Y, Cane MA. 2000. Interannual variability of Caribbean rainfall, ENSO, and the Atlantic Ocean. J. Clim. 13(2): 297-311.

Giannini A, Cane MA, Kushnir Y. 2001. Interdecadal changes in the ENSO teleconnection to the Caribbean region and the North Atlantic oscillation. J. Clim. 14(13): 2867-2879.

Huffman GJ, Bolvin DT, Nelkin EJ, Wolff DB, Adler RF, Guojun G, Yang H, Bowman KP, Stocker EF. 2007. The TRMM multisatellite precipitation analysis (TMPA): quasi-global, multiyear, combined-sensor precipitation estimates at fine scales. J. Hydrometeorol. 8(1): 38-55. https://doi.org/10.1175/JHM560.1.

Jury M, Malmgren BA, Winter A. 2007. Subregional precipitation climate of the Caribbean and relationships with ENSO and NAO. J. Geophys. Res. 112(D16): D16107. https://doi.org/10.1029/ 2006JD007541.

Kalnay E, Kanamitsu M, Kistler R, Collins W, Deaven D, Gandin L, Iredell M, Saha S, White G, Woollen J, Zhu Y, Leetmaa A, Reynolds R. 1996. The NCEP/NCAR 40 year reanalysis project. Bull. Am. Meteorol. Soc. 77: 437-471.

Karnauskas KB, Seager R, Giannini A, Busalacchi AJ. 2013. A simple mechanism for the climatological midsummer drought along the Pacific Coast of Central America. Atmosfera 26(2): 261-281.

Kelly P, Mapes B. 2011. Zonal mean wind, the Indian monsoon, and July drying in the western Atlantic subtropics. J. Geophys. Res 116: D00Q07. https://doi.org/10.1029/2010JD015405.

Kelly P, Mapes B. 2013. Asian monsoon forcing of subtropical easterlies in the 665 community atmosphere model: summer climate implications for the western 666 Atlantic. J. Clim. 26: 2741-2755. https://doi .org/10.1175/JCLI-D-12-00339.1.

Kelly P, Mapes B. 2016. February drying in southeast Brazil and the Australian monsoon: global mechanism for a regional rainfall feature. J. Clim. 29: 7529-7546. https://doi.org/10.1175/JCLI-D-15-0838.1.

Kirtman BP, Bitz C, Bryan F, Collins W, Dennis J, Hearn N, Kinter JL, Loft R, Rousset C, Siqueira L, Stan C, Tomas R, Vertenstein M. 2012. Impact of ocean model resolution on CCSM climate simulations. Clim. Dyn. 39(6): 1303-1328. https://doi.org/10.1007/s00382-0121500-3.

Kodama Y. 1992. Large scale features of subtropical precipitation zones (the Baiu Frontal zone, the SPCZ, and the SACZ). Part I: characteristics of subtropical fontal zones. J. Meteorol. Soc. Jpn. 70(4): 813-836.

Kodama Y-M. 1993. Large scale common features of subtropical convergence zones. Part II: conditions for the circulations. J. Meteorol. Soc. Jpn. 71(5): 581-610.

Kosaka Y, Xie S-P, Nakamura H. 2011. Dynamics of interannual variability in summer precipitation over East Asia. J. Clim. 24(20): 5435-5453. https://doi.org/10.1175/2011JCLI4099.1.

Lackmann G. 2011. Midlatitude Synoptic Meteorology: Dynamics, Analysis, and Forecasting. University of Chicago press: Chicago, IL.

Liang A. 2004. Cases of heavy precipitation and flash floods in the Caribbean during El Nino winters. J. Hydrometeorol. 5: 578-594.

Liebmann B, Smith CA. 1996. Description of a complete (interpolated) outgoing longwave radiation dataset. Bull. Am. Meteorol. Soc. 77: $1275-1277$.

Magaña V, Amador JA, Medina S. 1999. The midsummer drought over Mexico and Central America. J. Clim. 12(6): 1577-1588.

Maloney ED, Esbensen SK. 2007. Satellite and buoy observations of boreal summer intraseasonal variability in the tropical northeast Pacific. Mon. Weather Rev. 135(1): 3-19. https://doi.org/10.1175/ MWR3271.1.

Mapes BE. 2000. Convective inhibition, subgridscale triggering, and stratiform instability in a toy tropical wave model. J. Atmos. Sci. 57: $1515-1535$.

Mapes BE, Liu P, Buenning N. 2005. Indian monsoon onset and the Americas midsummer drought: out-of-equilibrium responses to smooth seasonal forcing. J. Clim. 18: 1109-1115.

Martin ER, Schumacher C. 2011. Modulation of Caribbean precipitation by the Madden-Julian oscillation. J. Clim. 24(3): 813-824. https://doi .org/10.1175/2010JCLI3773.1.

Minobe S, Kuwano-Yoshida A, Komori N, Xie S-P, Justin Small R. 2008. Influence of the Gulf Stream on the troposphere. Nature 452(7184): 206-209. https://doi.org/10.1038/nature06690.

Misra V, Li H, Kozar M. 2014. The Precursors in the Intra-Americas Seas to Seasonal Climate Variations over North America. J. Geophys. Res. Oceans 119: 2938-2948. https://doi.org/10.1002/2014JC009911. 
Miyasaka T, Nakamura H. 2005. Structure and formation mechanisms of the Northern Hemisphere summertime subtropical highs. J. Clim. 18(23): 5046-5065.

Molinari J, Vollaro D. 2012. A subtropical cyclonic gyre associated with interactions of the MJO and the midlatitude jet. Mon. Weather Rev 140: $343-357$.

Muñoz E, Busalacchi AJ, Nigam S, Ruiz-Barradas A. 2008. Winter and summer structure of the Caribbean low-level jet. J. Clim. 21(6) 1260-1276. https://doi.org/10.1175/2007JCLI1855.1.

Ninomiya K. 1984. Characteristics of Baiu front as a predominant subtropical front in the summer northern hemisphere. J. Meteorol. Soc. Jpn. 62(6): 880-894.

Ninomiya K, Shibagaki Y. 2003. Cloud system families in the Meiyu-Baiu front observed during 1-10 July 1991. Journal of the Meteorological Society or Japan 81(2): 193-209.

Park H-S, Lintner BR, Boos WR, Seo K-H. 2015. The effect of midlatitude transient eddies on monsoonal southerlies over eastern China. $J$. Clim. 28: 8450-8465. https://doi.org/10.1175/JCLI-D-15-0133.1.

Peters O, Neelin JD. 2006. Critical phenomena in atmospheric precipitation. Nat. Phys. 2(6): 393-396.

Poveda G, Mesa O. 2000. On the existence of Lloro (the rainiest locality on Earth): enhanced ocean-land-atmosphere interaction by a low level jet. Geophys. Res. Lett. 27(11): 1675-1678.

Rienecker MM, Suarez MJ, Gelaro R, Todling R, Bacmeister J, Liu E, Bosilovich MG, Schubert SD, Takacs L, Kim G-K, Bloom S, Chen J, Collins D, Conaty A, da Silva A, Gu W, Joiner J, Koster RD, Lucchesi R, Molod A, Owens T, Pawson S, Pegion P, Redder CR, Reichle R, Robertson FR, Ruddick AG, Sienkiewicz M, Woollen J. 2011 MERRA: NASA's modern-era retrospective analysis for research and applications. J. Clim. 24(14): 3624-3648. https://doi.org/10.1175/ JCLI-D-11-00015.1.
Sampe T, Xie S-P. 2010. Large scale dynamics of the Meiyu-Baiu rainband: environmental forcing by the westerly jet. J. Clim. 23: 113-134. https://doi.org/10.1175/2009JCLI3128.1.

Shapiro MA. 1981. Frontogenesis and geostrophically forced secondary circulations in the vicinity of jet stream-frontal zone systems. J. Atmos. Sci. 38: 954-973.

Small RJO, de Szoeke SP, Xie S-P. 2007. The Central American midsummer drought: regional aspects and large-scale forcing. J. Clim. 20(19): 4853-4873. https://doi.org/10.1175/JCLI4261.1.

Spence JM, Taylor MA, Chen AA. 2004. The effect of concurrent sea-surface temperature anomalies in the tropical Pacific and Atlantic on Caribbean rainfall. Int. J. Climatol 24(12): 1531-1541. https://doi .org/10.1002/joc.1068.

Taylor MA, Whyte FS, Stephenson TS, Campbell JD. 2013. Why dry? Investigating the future evolution of the Caribbean low level jet to explain projected Caribbean drying. Int. J. Climatol. 33(3): 784-792. https://doi.org/10.1002/joc.3461.

Waliser DE, Gautier C. 1993. A satellite-derived climatology of the ITCZ. J. Clim. 6: 2162-2174.

Wang B. 2005. The Asian Monsoon. Springer/Praxis Publishing Co.: New York, 787 pp.

Wang B, LinHo YZ, Lu M-M. 2004. Definition of South China Sea monsoon onset and commencement of the East Asia summer monsoon. $J$. Clim. 17: 699-710.

Whyte FS, Taylor MA, Stephenson TS, Campbell JD. 2007. Features of the Caribbean low level jet. Int. J. Climatol. 28(1): 119-128. https:// doi.org/10.1002/joc. 1510

Yoshida A, Minobe S, Xie S-P. 2010. Precipitation response to the Gulf stream in an atmospheric GCM. J. Clim. 23(13): 3676-3698. https:// doi.org/10.1175/2010JCLI3261.1. 